\title{
Gestational, perinatal and family findings of patients with Patau syndrome
}

\author{
Achados gestacionais, perinatais e familares de pacientes com síndrome de Patau \\ Hallazgos gestacionales, perinatales y familiares de pacientes con síndrome de Patau
}

Rafael Fabiano M. Rosa ${ }^{1}$, Melina Vaz Sarmento ${ }^{1}$, Janaina Borges Polli ${ }^{1}$, Daniela de Paoli Groff', Patrícia Petry ${ }^{1}$, Vinícius Freitas de Mattos ${ }^{2}$, Rosana Cardoso M. Rosa ${ }^{3}$, Patrícia Trevisan ${ }^{4}$, Paulo Ricardo G. Zen ${ }^{4}$

\section{ABSTRACT}

Objective: To describe gestational, perinatal and family findings of patients with Patau syndrome (PS).

Methods: The study enrolled patients with PS consecutively evaluated during 38 years in a Clinical Genetics Service of a pediatric referral hospital in Southern Brazil. The clinical data and the results of cytogenetic analysis were collected from the medical records. For statistical analysis, the two-tailed Fisher's exact test and the chi-square test with Yates' correction were used, being significant $p<0.05$.

Results: The sample was composed of 27 patients, $63 \%$ were male, with a median age of nine days at the first evaluation. Full trisomy of chromosome 13 was the main cytogenetic finding (74\%). Only six patients were submitted to obstetric ultrasound and none had prenatal diagnosis of PS. The patients' demographic characteristics, compared to born alive infants in the same Brazilian state showed a higher frequency of: mothers with 35 years old or more (37.5\%); multiparous mothers (92.6\%); vaginal delivery (77\%); preterm birth (34.6\%); birth weight $<2500 \mathrm{~g}$ (33.3\%), and Apgar scores $\leq 7$ in the $1^{\text {st }}(75 \%)$ and in the $5^{\text {th }}$ minute $(42.9 \%)$. About half of them (53\%) died during the first month of life.

Conclusions: The understanding of the PS patients' gestational, perinatal and family findings has important implications, especially on the decision about the actions to be taken in relation to the management of these patients.

Instituição: Universidade Federal de Ciências da Saúde de Porto Alegre (UFCSPA) e Complexo Hospitalar Santa Casa de Porto Alegre

${ }^{1}$ Hospital Materno Infantil Presidente Vargas, Porto Alegre, RS, Brasil

2UFCSPA; Complexo Hospitalar Santa Casa de Porto Alegre, Porto Alegre,

RS, Brasil

${ }^{3}$ Grupo Hospitalar Conceição, Porto Alegre, RS, Brasil

${ }^{4}$ UFCSPA, Porto Alegre, RS, Brasil
Key-words: chromosomes, human, pair 13; chromosome aberrations; infant, premature; Apgar score; prenatal diagnosis; prognosis.

\section{RESUMO}

Objetivo: Descrever os achados gestacionais, perinatais e familiares de pacientes com síndrome de Patau (SP).

Métodos: Esta pesquisa envolveu pacientes com diagnóstico de SP avaliados consecutivamente durante 38 anos no Serviço de Genética de um hospital pediátrico de referência do sul do país. Os dados clínicos e os resultados da análise citogenética foram coletados dos prontuários médicos. Para a análise estatística, utilizaram-se o teste exato de Fisher bicaudado e o teste do qui-quadrado com correção de Yates $(p<0,05)$.

Resultados: A amostra foi composta por 27 pacientes, $63 \%$ do sexo masculino, com mediana de idade na primeira avaliação de nove dias. A trissomia livre do cromossomo 13 foi o principal achado citogenético $(74 \%)$. Somente seis pacientes apresentavam relato de ultrassom obstétrico e nenhum teve diagnóstico pré-natal de SP. Ao comparar os dados da presente amostra com os dados de nascidos vivos do mesmo estado, observou-se que, para os pacientes com SP, houve maior frequência de mães com idade $\geq 35$ anos (37,5\%); multíparas (92,6\%); parto vaginal (77\%), prematuridade $(34,6 \%)$, peso ao nascer $<2500 \mathrm{~g}(33,3 \%)$ e escore de Apgar $\leq 7$ no $1^{\circ}(75 \%)$ e $5^{\circ}$ minuto $(42,9 \%)$. Cerca de metade dos pacientes $(53 \%)$ morreu no primeiro mês de vida.
Endereço para correspondência:

Paulo Ricardo G. Zen

Rua Sarmento Leite, 245, sala 403 - Centro

CEP 90050-170 - Porto Alegre/RS

E-mail: paulozen@ufcspa.edu.br

Conflito de interesse: nada a declarar

Recebido em: 5/4/2013

Aprovado em: 12/6/2013 
Conclusões: O entendimento dos achados gestacionais, perinatais e familiares da SP leva a importantes repercussões, especialmente sobre a decisão quanto às condutas a serem tomadas no manejo desses pacientes.

Palavras-chave: cromossomos humanos par 13; aberrações cromossômicas; prematuro; índice de Apgar; diagnóstico pré-natal; prognóstico.

\section{RESUMEN}

Objetivo: Describir los hallazgos gestacionales, perinatales y familiares de pacientes con síndrome de Patau (SP) y compararlos con los de la población de nacidos vivos de la misma provincia, Rio Grande do Sul, presentes en la base de datos del Sistema Único de Salud (DATASUS).

Métodos: Esa investigación implicó a pacientes con diagnóstico de SP evaluados consecutivamente durante 38 años en el Servicio de Genética de un hospital pediátrico de referencia en el sur de Brasil. Los datos clínicos y los resultados del análisis citogenético fueron recogidos de los prontuarios médicos. Para el análisis estadístico, se utilizaron la prueba exacto de Fisher bicaudado y la prueba del chi cuadrado con corrección de Yates $(p<0,05)$.

Resultados: La muestra fue compuesta por 27 pacientes, el $63 \%$ del sexo masculino, con mediana de edad en la primera evaluación de nueve días. La trisomía libre del cromosoma 13 fue el principal hallazgo citogenético (74\%). Solamente seis pacientes presentaban relato de ultrasonografía obstétrica y ninguno tuvo diagnóstico pre-natal de SP. Al comparar los datos de esa muestra con los datos de nacidos vivos en la misma provincia, se observó que, para los pacientes con SP, hubo mayor frecuencia de madres con edad $\geq 35$ años (37,5\%); multíparas (92,6\%); parto vaginal $(77 \%)$; prematuridad $(34,6 \%)$; peso al nacer $<2.500 \mathrm{~g}$ $(33,3 \%)$ y escore de Apgar $\leq 7$ en el $1^{\circ}(75 \%)$ y $5^{\circ}$ minuto $(42,9 \%)$. Aproximadamente mitad de los pacientes (53\%) murió en el primer mes de vida.

Conclusiones: El entendimiento de los hallazgos gestacionales, perinatales y familiares de SP lleva a importantes repercusiones, especialmente sobre la decisión respecto a las conductas a tomar en el manejo de esos pacientes.

Palabras clave: cromosomas humanos par 13; aberraciones cromosómicas; prematuro; índice de Apgar; diagnóstico prenatal; pronóstico.

\section{Introduction}

Trisomy 13, or Patau syndrome (PS), was first described in 1960 by Patau et $a l^{(1)}$. Since then, there have been numerous reports of the syndrome, as its prevalence is estimated at 1:20.000-29.000 live births ${ }^{(2,3)}$. Thus, the PS is a relatively frequent and recurrent condition, considered the third most common trisomy of autosomes, only behind Down syndrome (trisomy 21) and Edwards syndrome (trisomy 18). It is characterized by a usually recognizable scenario of multiple congenital anomalies, associated to a poor prognosis. About $67 \%$ of fetuses with PS are spontaneously aborted or have intrauterine death; and among those who come alive at birth, $50 \%$ end up dying in the 1st week of life and only $9 \%$ reach the 1 st year ${ }^{(4,5)}$. In the literature, it is noteworthy the paucity of data regarding pregnancy, birth, and family of patients with PS ${ }^{(3,6-13)}$, although they are very important for diagnosis, appropriate management, and genetic counseling to family members ${ }^{(4)}$.

Thus, this study examined the pregnancy, perinatal, and family findings of patients with PS and compared them to the population in general, present especially in the database of the National Health System of Brazil (DATASUS).

\section{Method}

Study of a case series, descriptive and retrospective, which involved patients with diagnosis of PS, evaluated consecutively in Clinical Genetics of a referral hospital in southern Brazil. Patients were considered with PS only upon diagnostic proof conducted with karyotype examination.

The period analyzed was from 1975 to 2012. These patients were part of the study sample developed by Petry et al $^{(14)}$, who assessed the presence of clinical abnormalities (including congenital heart defects) and prognosis. Clinical data and results of the cytogenetic analysis were collected retrospectively from the medical records of the patients. Data consisted primarily of sex, age of patients at the time of initial evaluation, maternal and paternal ages, prenatal care, maternal disease, threatened abortion (defined as the occurrence of vaginal bleeding before viability), obstetric ultrasound, prenatal diagnosis, type of delivery and form of presentation, gestational age, and body measurements at birth (weight, length, and head circumference), Apgar scores at 1 and 5 minutes, survival (defined as the period from birth to the moment of death), parity, history of prior pregnancy 
loss, history of birth of children with PS or other chromosomal aneuploidies, and results of karyotype examination. Patients without these data, i.e., with incomplete medical records, were excluded from the study.

Advanced maternal age was established at $\geq 35$ years, and low birth weight when less than 2,500g. The birth weights of the patients were also evaluated according to gestational age, and those below the 10th percentile were considered small, according to the growth curves described by Margotto ${ }^{(15)}$. As for obstetric ultrasound, we considered only those who held at least one exam after the 18th week of gestation. As for Apgar scores, patients were classified into values $\leq 7$ (indicative of some degree of anoxia) and $>7$. Regarding parity, mothers of patients were classified as primiparous or multiparous and with number of pregnancies $\geq 4$ or not. To obtain survival data from this sample, we carried out a consultation with the Center of Health Information (NIS) of the Health Department of the State of Rio Grande do Sul.

We compared data from the study with those observed in the general population - present in the vital statistics of the state of Rio Grande do Sul and described in the DATASUS database (www.datasus.gov.br/) ${ }^{(16)}$, using an average of the values reported between the years 1994 and 2010, and in studies, especially local, reported in the literature.

The present study was approved by the Research Ethic Committee of Universidade Federal de Ciências da Saúde de Porto Alegre (UFCSPA), according to opinion n. 929/09. For statistical analysis, we used the PEPI program (version 4.0), using the two-tailed Fisher exact test and the chi-square test with Yates' correction, available at http://quantpsy.org ${ }^{(17)}$, establishing significance at $p<0.05$.

\section{Results}

During the study period, we identified 30 patients with PS among the 10,561 assessed by the Service, comprising $0.3 \%$ of the total. Among these, three had incomplete medical records and were excluded. Among the 27 patients who comprised the sample, $63 \%$ were male, with ages ranging from 1 to 388 days in the first assessment (median: 9 days; mean $=35.5$ days). We evaluated 18 patients before the $2000 \mathrm{~s}$ $(67 \%)$ and nine (33\%) from the 2000s. Among the latter, five, (56\%) were analyzed before 2006 and four (44\%), later.

Regarding cytogenetics, the full trisomy of chromosome 13 was the main finding $(\mathrm{n}=20 ; 74 \%)$. Among the remaining, $7.5 \%(n=2)$ had a translocation and $18.5 \%(n=5)$, mosaicism. Both cases had translocation between chromosomes 13 and 14 [der(13;14)]. In one case, we also performed the karyotype of the parents, verifying that the mother was a balanced carrier of the same translocation.

Maternal age at birth ranged from 18 to 45 years (mean $=30.7$ years) and $37.5 \%$ were aged $\geq 35$ years. In all these cases, the chromosome constitution of patients was full trisomy of chromosome 13 . The parents' ages ranged from 20 to 52 years, with a mean equal to the maternal, 30.7 years. Among all patients, $96.3 \%$ received prenatal care. Maternal diseases were reported in five cases (15.4\%) and consisted of urinary tract infection $(\mathrm{n}=2)$, preeclampsia $(\mathrm{n}=2)$, increased blood pressure $(\mathrm{n}=1)$ and anemia $(\mathrm{n}=1)$. Threatened abortion was reported in $7.7 \%$ of cases. Only six patients $(22 \%)$ reported at least one obstetric ultrasound after 18 weeks of gestation. However, we highlight the fact that, in four of them $(66.7 \%)$, the examination was considered normal. In two cases with changed ultrasound, the changes consisted of hydrocephaly $(\mathrm{n}=1)$ and hydronephrosis $(n=1)$. None of the patients underwent procedures such as amniocentesis for fetal karyotyping or had prenatal diagnosis of PS (Table 1).

Regarding the mode of delivery, 23\% ( $\mathrm{n}=6)$ were cesarean, due, mainly to breech presentation, $(n=4)$. Other reasons included hydrocephaly $(\mathrm{n}=1)$ and fetal distress $(\mathrm{n}=1)$. As for the presentation, $20 \%$ of cases were breech. Prematurity was observed in $34.6 \%$ of patients. Birth weight ranged from $1,875$ to $3,830 \mathrm{~g}$ (mean $=2,681 \mathrm{~g})$. Low weight $(<2,500 \mathrm{~g})$ was verified in $33.3 \%$ of cases. Seven patients $(25.9 \%)$ were small for gestational age. The length at birth ranged from 42 to $52 \mathrm{~cm}($ mean $=46.3 \mathrm{~cm})$ and head circumference ranged from 27 to $34.5 \mathrm{~cm}$ (mean=30.1cm). As for Apgar scores, indexes $\leq 7$ were observed in $75 \%$ of cases in the $1 \mathrm{st}$ minute and $42.9 \%$ in the 5 th. We obtained data regarding survival of 17 patients, and of these, nine (53\%) died within the 1 st month of life. The median survival was 26 days and the earliest death occurred at 4 days, with two patients still living with more than 8 years old.

Regarding maternal parity, the number of pregnancies ranged from one to 11 (mean=3.6), and $37 \%$ had number of pregnancies $\geq 4$. Two cases $(7.4 \%)$ were primiparous. Prior history of abortion was found in $25.9 \%$ of cases (all had only one pregnancy loss). There was one case report (5\%) of previous birth of a child with Down syndrome from a previous marriage of a parent of children with PS. When the child with PS was born, this father was 32 years (the daughter with Down syndrome was born when her father 
Table 1 - Gestational, perinatal and family findings of patients with Patau syndrome (PS) in the present sample and in the literature

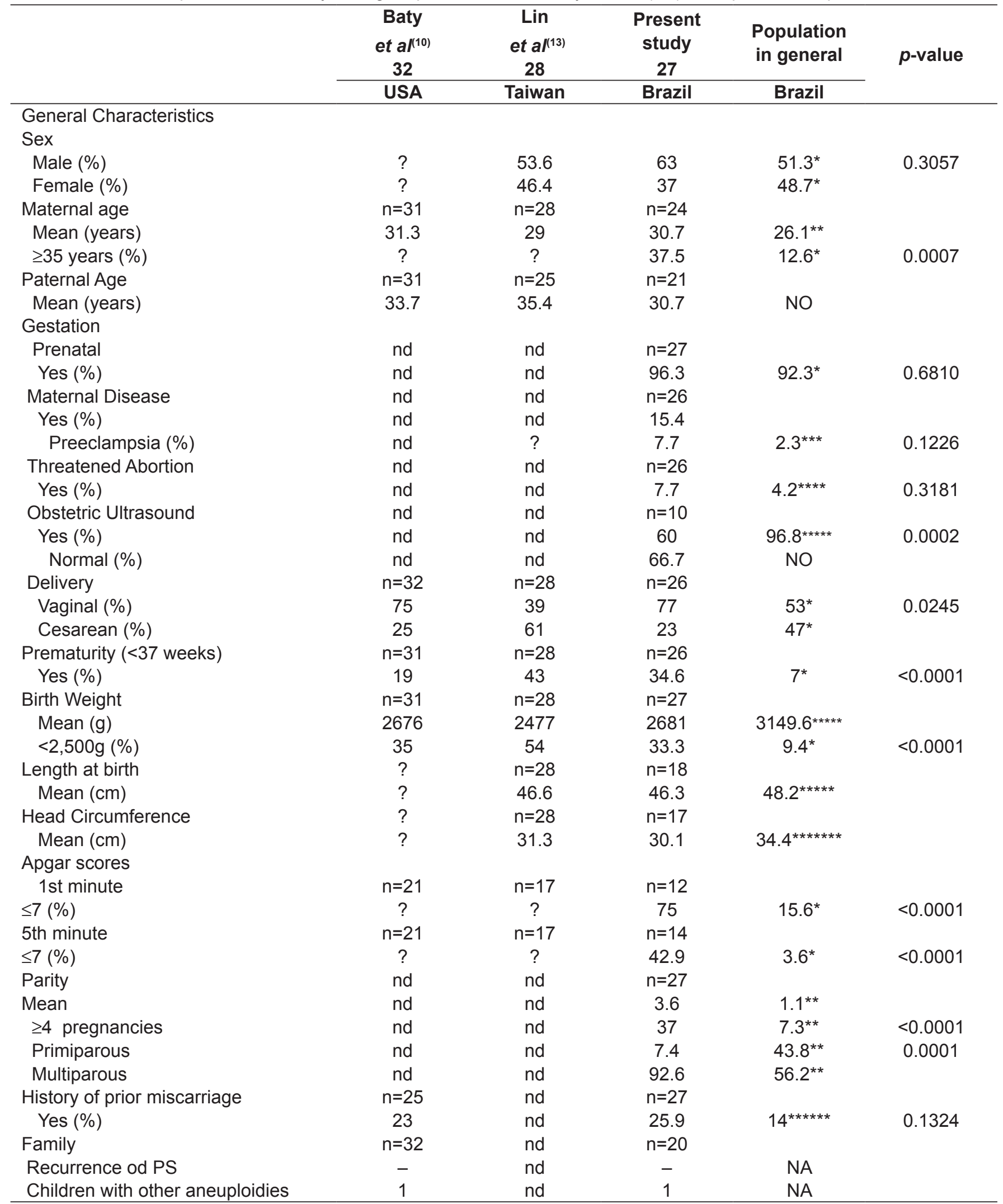

ND: not described; ?: Questioned; NA: not applicable; NO: data not obtained or unknown; *DATASUS ${ }^{(16) ; ~ * *}$ Santos et a/(18); *** Gaio et al(23); *** $S t e i n-$ Backes e Flores-Soares ${ }^{(26) ;}{ }^{* * * * *}$ Barros et $a^{(28) ;}{ }^{* * * * * *}$ Cecatti et $a{ }^{(31) ;} ;{ }^{* * * * * *}$ Mota et al ${ }^{(29)}$ 
was 22 years old). There was no recurrence of PS, even in cases involving translocations (Table 1).

In the literature review, we found few studies describing the findings related to pregnancy, perinatal, and family members of patients with $\mathrm{PS}^{(3,6-13)}$. Only two of them were held in Latin America, both also in Brazil, involving the same sample of patients ${ }^{(11,12)}$. However, they are not in journals indexed in PubMed and SciELO. The main studies may be seen in detail in Table 1.

\section{Discussion}

The frequency observed in this study with males and females was similar to that found for Rio Grande do Sul in the database DATASUS ${ }^{(16)}(p=0.31)$ (Table 1). This finding is also in line with Taylor ${ }^{(7)}$. However, Lin et al noted a slight predominance of males with PS $(53.6 \%)^{(13)}$. On the other hand, Magenis et al, Hodes et al e Sugayama et al observed a little higher frequency of female subjects $(52,57$, and $55 \%$, respectively $)^{(6,8,11)}$. However, these differences were not statistically significant.

The mean maternal age at birth observed in this sample (30.7 years) was within the range reported in other studies involving patients with PS (28.2 to 31.6 years) $)^{(3,7,9,10,13)}$. The average reported for the general population in Brazilian studies is 26.1 years $^{(18)}$. The frequency of mothers aged $\geq 35$ years observed in this study $(37.5 \%)$ was higher than that described in the DATASUS database ${ }^{(16)}(12.6 \%)(p=0.0007)$. In all these cases, the chromosome constitution of patients was full trisomy of chromosome 13 , which correlated with maternal age and the phenomenon of non-disjunction of chromosomes, especially during meiosis $\mathrm{I}^{(19)}$. Magenis et $\mathrm{al}^{(6)} \mathrm{e}$ Sugayama et $\mathrm{al}^{(11)}$ found a mean age of 31.7 and of 28.3 years, respectively, for mothers of children with PS with full trisomy of chromosome 13. Furthermore, Magenis et al ${ }^{(6)}$ observed a likely bimodal distribution for maternal age, with the 1st peak occurring around 25 years and the second, around 38 years. Maternal and paternal ages seem inevitably correlated $^{(6,7)}$, and the mean paternal age at birth in the present study was identical to the maternal (30.7 years). In the literature, the mean described for parents of patients with PS ranged from 29.4 to 35.4 years $^{(7,9,10,13)}$ (Table 1).

The frequency of prenatal care among patients with PS (96.3\%) was similar to that described in the general population $(92.3 \%)^{(16)}(p=0.68)$. They reported maternal diseases in $15.4 \%$ of our cases. Despite the association described in the literature between fetuses with PS and preeclampsia ${ }^{(20-22)}$, there was no difference between the frequency noted in cases described here $(7.7 \%)$ and in pregnant women in general $(2.3 \%)^{(23)}(p=0.12)$ (Table 1). Perhaps this is related to the low frequency $(7.4 \%)$ of primiparous mothers (a risk factor well associated with preeclampsia) in this study in comparison to pregnant women in general $(43.8 \%)^{(18)}(p=0.0001)$ or the actual sample size. On the other hand, the sample presented here had numerous women with advanced age (greater frequency than that observed in pregnant women in general $)^{(18)}(p=0.0071)$ (Table 1), which is also associated with a higher risk of preeclampsia ${ }^{(23,24)}$. However, none of the mothers of the patients in our study with the description of preeclampsia were primiparous or had advanced age. Interestingly, placental abnormalities are described with great frequency in pregnancies of fetuses with PS and include small placental volume, reduced placental vascularization, a partial molar appearance of the placenta, and placental mesenchymal dysplasia ${ }^{(25)}$. These placental abnormalities were not described in this study, especially due to the lack of placental analysis.

The rate of threatened abortion $(7.7 \%)$ was similar to that of the general population of pregnant women $(4.2 \%)^{(26)}$ $(p=0.32)$ (Table 1). In the literature, there are no reports of this variable in other studies with patients with PS. Only 6 patients in this study $(22.2 \%)$ relied on obstetric ultrasound. Perhaps this relates to the fact that, in Brazil, the ultrasound started to be offered as a routine examination in public health, especially from the 2000s. However, it was noted that, in four cases $(66.7 \%)$, the examination was considered normal (Table 1). Anyway, none of the patients in this sample were subjected to procedures such as amniocentesis for fetal karyotyping or had prenatal diagnosis of PS, suggesting a possible failure in our system. This finding was also observed by Rosa et a ${ }^{(27)}$ in patients with trisomy 18 (Edwards syndrome). However, we should also consider that, Brazilian Law does not allow termination of pregnancies of fetuses with PS allowed in Brazil. Therefore, it is believed that this aspect has not influenced our results.

Regarding the mode of delivery, $23 \%$ were cesarean. Interestingly, this rate was lower than the general population $(47 \%)^{(16)}(p=0.0245)$. Even so, this frequency was statistically similar to Baty et al ${ }^{(10)}(25 \%)(p=1.0000)$ and Sugayama et $a^{(12)}$ (other Brazilian study, with $\left.42 \%\right)(p=0.21$ ). In addition, Lin et al ${ }^{(13)}$ found higher rates $(61 \%)(p=0.0067)$ (Table 1). Perhaps these findings relate to the low sonographic detection of PS and, hence, of prenatal diagnosis. In the case series described here, the main reason of cesarean 
indication was breech presentation (66.7\%). In the study by Lin et $a l^{(13)}$, such indication occurred only in 6\% $(p=0.0078)$. Of all births in this sample of patients, it was found breech presentation in $20 \%$ of cases, similar index to that described by Baty et $a l^{(10)}(13 \%)(p=0.6849)$ and Sugayama et al $l^{(12)}$ $(17 \%)(p=1.0000)$.

The prematurity rate observed here $(34.6 \%)$ was higher than the general population (7\% $)^{(16)}(p<0.0001)$, however, similar to other studies with PS (19 to $63.6 \%)^{(9,10,12,13)}$. The mean birth weight was $2,681 \mathrm{~g}$, a value close to the variability described in the literature $(2,477 \text { to } 2,676 \mathrm{~g})^{(7,10,13)}$ and lower than that of the general population $(3,149 \mathrm{~g})^{(28)}$ (Table 1). Sugayama et al ${ }^{(12)}$ reported mean birth weight of $2,255 \mathrm{~g}$ for the preterm newborns with PS and of 2,539g for term infants. It was observed low birth weight $(<2,500 \mathrm{~g})$ in $33.3 \%$ of our cases, an index much higher than the rate of the general population $(9.4 \%)^{(16)}(p<0.0001)$. This may have been influenced by the high prematurity rate observed in our sample. Among the 9 patients with birth weight $<2,500 \mathrm{~g}$, six $(66.7 \%)$ were small for gestational age. In the literature, the weight ratio among patients with low PS is similar to the present study and ranges from 35 to $54 \%^{(10,13)}$ (Table 1 ).

The average length at birth of patients analyzed in this study was $46.3 \mathrm{~cm}$; in the literature, in individuals with PS, the mean was $46.6 \mathrm{~cm}^{(13)}$. In the population in general, Barros et $\mathrm{al}^{(28)}$ found a slightly higher rate of $48.2 \mathrm{~cm}$. As or the head circumference, the mean of this study was $30.1 \mathrm{~cm}$, which is close to that of Lin et $a l^{(13)}$ (Table 1). Sugayama et $\mathbf{l}^{(12)}$ found the value of $29.3 \mathrm{~cm}$ for preterm children with PS and of $32.5 \mathrm{~cm}$ for those born at term. In Mota et al ${ }^{(29)}$, the mean head circumference found in the general population was higher, $34.4 \mathrm{~cm}$ (Table 1), indicating that microcephaly is a common finding in patients with PS, which is consistent with the description held in the literature ${ }^{(10)}$.

Regarding Apgar scores, indexes $\leq 7$ were observed in $75 \%$ of cases, at 1 minute, and $42.9 \%$, at 5 . These frequencies were much higher than those described in the database of DATASUS (15.6 and 3.6\%, respectively) ${ }^{(16)}(p<0.0001$ for both Apgar scores) (Table 1). In this study, we considered the Apgar scores $\leq 6$ for the 1st and 5th minutes (66.7 and $14.3 \%$, respectively), the frequencies were similar to those described in the literature for patients with PS (in the 1st minute, 53 to $62 \%$; in the 5 th, 12 to $33 \%)^{(10,13)}$.

A significant number of patients died within the 1 st month of life $(53 \%)$, which is compatible with the gravity associated with the PS. Further discussion on these aspects can be seen in Petry et $a l^{(14)}$. The poor prognosis associated to PS generates intense controversy regarding the management, including the implementation of interventions or not. However, in Brazil, there are no laws regarding cardiopulmonary resuscitation of newborns with PS. According to the Neonatal Resuscitation Program of the Brazilian Society of Pediatrics ${ }^{(30)}$, in the case of congenital malformations, it is necessary to have antenatal diagnostic verification and consider the parents' wish and the existing therapeutic advances to decide the conduct to be taken in the delivery room. However, as it can be seen in this study, the prenatal diagnosis of PS in our environment seems to be poor. Another aspect to be considered relates to the survival achieved by some patients with the syndrome. In this sample, for instance, three individuals (18\%) exceeded the age of 8. These findings may have important implications on the management of patients.

Regarding parity, the number of pregnancies in this study ranged from 1 to11. The mean was 3.6 pregnancies, higher than that described in the general population (1.1 pregnancies $^{(18)}$ (Table 1$)$. In the same study, $37 \%$ of mothers were $\geq 4$, in relation to the $7.3 \%$ of pregnant women in general ${ }^{(18)}$ $(p<0.0001)$. It is believed that this finding is related to the frequency of mothers with advanced age in the sample. The frequency of primiparous mothers in this study, as stated earlier, was also quite low.

Regarding prior history of abortion, it was found that it was positive in $25.9 \%$ of cases, an index statistically similar to the population in general $(14 \%)^{(31)}(p=0.13)$ (Table 1). Taylor ${ }^{(7)}$ reported that, in their sample, mothers of children with PS had 68 pregnancies, of which five $(7.4 \%)$ ended in known spontaneous miscarriage, an index lower than that of this study $(p=0.0340)$.

There was no recurrence of PS, even in cases involving translocations, which, was consistent with the findings of Baty et $a^{(10)}$ (Table 1), showing how rare is the recurrence of PS. Interestingly, the risk observed even in cases of translocation, in which this chromosomal abnormality is identified also in one of the parents, it is lower than $1 \%$, especially due to the wide selection in utero ${ }^{(32)}$. There was only one case described in this study of a previous birth of a child with Down syndrome, from another marriage of one of the parents with PS. In turn, Baty et al ${ }^{(10)}$ also found a case with previous birth of a child with trisomy 18 (Edwards syndrome).

Because it refers to a very long period of time (1975-2012), changes in clinical practice in the period probably influenced the results of this investigation. Thus, especially the realization of 
ultrasound in prenatal care and the lower frequency of prenatal diagnosis may be a consequence of these differences over time. This sample consisted of patients with PS treated at the Genetics Service of the Hospital and with diagnostic verification conducted by karyotype. There may have been suspected cases that have died before evaluation, due to its severity. Furthermore, this is a retrospective study, with data collection from medical records, subject, therefore, to a possible measurement bias.
Anyhow, the understanding of the findings on pregnancy, perinatal, and family of PS patients can lead to significant repercussions, especially regarding the decisions related to actions to be taken in the clinical management and genetic counseling of these patients and their families. Furthermore, despite the small sample size of this study and the long period of evaluation, the lack of prenatal diagnosis of PS is noteworthy in our location.

\section{References}

1. Patau K, Smith DW, Therman E, Inhorn SL, Wagner HP. Multiple congenital anomaly caused by an extra autosome. Lancet 1960;1:790-3.

2. Goldstein $\mathrm{H}$, Nielsen KG. Rates and survival of individuals with trisomy 13 and 18. Data from a 10-year period in Denmark. Clin Genet 1988;34:366-72.

3. Wyllie JP, Wright MJ, Burn J, Hunter S. Natural history of trisomy 13. Arch Dis Child 1994;71:343-5.

4. Carey JC. Trisomy 18 and trisomy 13 syndromes. In: Cassidy SB, Allanson JE, editors. Management of genetic syndromes. $3^{\text {rd }}$ ed. New york: Willey-Blackwell; 2010. p. 807-23.

5. Lakovschek IC, Streubel B, Ulm B. Natural outcome of trisomy 13, trisomy 18, and triploidy after prenatal diagnosis. Am J Med Genet A 2011;155A:2626-33.

6. Magenis RE, Hecht F, Milham S Jr. Trisomy 13 (D1) syndrome: studies on parental age, sex ratio, and survival. J Pediatr 1968;73:222-8.

7. Taylor Al. Autosomal trisomy syndromes: a detailed study of 27 cases of Edwards' syndrome and 27 cases of Patau's syndrome. J Med Genet 1968;5:227-52.

8. Hodes ME, Cole J, Palmer CG, Reed T. Clinical experience with trisomies 18 and 13. J Med Genet 1978;15:48-60.

9. Moerman P, Fryns JP, van der Steen K, Kleczkowska A, Lauweryns J. The pathology of trisomy 13 syndrome. A study of 12 cases. Hum Genet 1988;80:349-56

10. Baty BJ, Blackburn BL, Carey JC. Natural history of trisomy 18 and trisomy 13: I. Growth, physical assessment, medical histories, survival, and recurrence risk. Am J Med Genet 1994;49:175-88.

11. Sugayama SM, Kim CA, Albano LM, Utagawa CY, Bertola DR, Koiffmann $\mathrm{CP}$ et al. Clinical and genetic study of 20 patients with trisomy 13 (Patau's syndrome). Pediatria (São Paulo) 1999;21:21-9.

12. Sugayama SM, Kim CA, Leone CR, Diniz EM, Koiffmann CP, Gonzalez $\mathrm{CH}$. Natural history of 24 patients with trisomy 18 (Edwards' syndrome) and 20 patients with trisomy 13 (Patau's syndrome). Pediatria (São Paulo) 1999;21:69-77.

13. Lin HY, Lin SP, Chen YJ, Hsu CH, Kao HA, Chen MR et al. Clinical characteristics and survival of trisomy 13 in a medical center in Taiwan, 19852004. Pediatr Int 2007;49:380-6.

14. Petry P, Polli JB, Mattos VF, Rosa RC, Zen PR, Graziadio C et al. Clinical features and prognosis of a sample of patients with trisomy 13 (Patau syndrome) from Brazil. Am J Med Genet A 2013;161:1278-83.

15. Margotto PR. Intrauterine growth curves: study of 4,413 single live births of normal pregnancies. J Pediatr (Rio J) 1995;71:11-21.

16. Brasil - Ministério da Saúde - DATASUS [homepage on the Internet]. Informações de Saúde: estatísticas vitais [cited 2013 Mar 20]. Available from: http://www2.datasus.gov.br/DATASUS/index.php
17. Preacher KJ, Briggs NE. Calculation for Fisher's exact test: an interactive calculation tool for Fisher's exact probability test for $2 \times 2$ tables [computer software]. Available from: http://www.quantpsy.org/fisher/fisher.htm

18. Santos IS, Barros AJ, Matijasevich A, Tomasi E, Medeiros RS, Domingues MR et al. Mothers and their pregnancies: a comparison of three population-based cohorts in Southern Brazil. Cad Saude Publica 2008;24 (Suppl 3):S381-9.

19. Hall HE, Chan ER, Collins A, Judis L, Shirley S, Surti U et al. The origin of trisomy 13. Am J Med Genet A 2007;143A:2242-8.

20. Boyd PA, Lindenbaum RH, Redman C. Pre-eclampsia and trisomy 13: a possible association. Lancet 1987;2:425-7.

21. Bower C, Stanley F, Walters BN. Pre-eclampsia and trisomy 13. Lancet 1987;2:1032.

22. Thornton JG, O'Donovan P, Stigter R, Williams J, Sullivan LG. Pre-eclampsia and trisomy 13. Lancet 1987;330:794.

23. Gaio DS, Schmidt MI, Duncan BB, Nucci LB, Matos MC, Branchtein L. Hypertensive disorders in pregnancy: frequency and associated factors in a cohort of Brazilian women. Hypertens Pregnancy 2001;20:269-81.

24. ACOG Committee on Practice Bulletins-Obstetrics. ACOG practice bulletin Diagnosis and management of preeclampsia and eclampsia. Number 33, January 2002. Obstet Gynecol 2002;99:159-67.

25. Chen CP. Placental abnormalities and preeclampsia in trisomy 13 pregnancies. Taiwan J Obstet Gynecol 2009;48:3-8.

26. Stein-Backes MT, Flores-Soares MC. Intercurrencies during pregnancy and their consequences on the weight of the newborn. Rev Colomb Obstet Ginecol 2008;59:103-10.

27. Rosa RF, Rosa RC, Lorenzen MB, de Moraes FN, Graziadio C, Zen PR et al Trisomy 18: experience of a reference hospital from the south of Brazil. Am J Med Genet A 2011;155A:1529-35.

28. Barros AJ, dos Santos IS, Victora CG, Albernaz EP, Domingues MR, Timm IK et al. The 2004 Pelotas birth cohort: methods and description. Rev Saude Publica 2006;40:402-13.

29. Mota M, Melo A, Burak C, Daltro C, Rodrigues B, Lucena R. Anthropometric cranial measures of normal newborn. Arq Neuropsiquiatr 2004;62:626-9.

30. Sociedade Brasileira de Pediatria [homepage on the Internet]. Programa de Reanimação Neonatal da Sociedade Brasileira de Pediatria: Condutas 2011 [cited 2013 Apr 27]. Available from: http://www.sbp.com.br/pdfs/PROGRAMA REANIMACAO_NEONATA.pdf

31. Cecatti JG, Guerra GV, Sousa MH, Menezes GM. Abortion in Brazil: a demographic approach. Rev Bras Ginecol Obstet 2010;32:105-11.

32. Zen PR, Rosa RF, Rosa RC, Dale Mulle L, Graziadio C, Paskulin GA. Unusual clinical presentations of patients with Patau and Edwards sydromes: a diagnostic challenge? Rev Paul Pediatr 2008;26:295-9. 